Covered in: ERIH PLUS, HeinOnline, CEEOL, Index Copernicus, CrossRef, CrossCheck, J-GATE, Google Scholar, Ideas RePeC, Econpapers, Socionet, KVK, WorldCat.

2020, Volume 8, Issue 1, pages: 35-46 | doi: 10.18662/lumenlaw/8.1/34

\section{Short Incursion in the History of Domestic Violence}

\section{Ioan TICU1}

${ }^{1}$ Drd. Ministerul Educației, Culturii şi Cercetării al Republicii Moldova, Universitatea de Studii Europene din Moldova, Şcoala doctorală - Ştiințe juridice și relații internaționale, Specialitatea - Drept internaţional şi european public.

ticuioan70@yahoo.com
Abstract: The article provides a brief description of the stages of activism development aiming to stop violence against women, starting from 1791 when the phenomenon begins to be recognized as being very dangerous as it flagrantly violates the fundamental human rights. There were made brief referrals to the development stages of soft and hard law governing the activism to stop violence against women of all kinds and to respect their rights.

Keywords: violence against women; soft laws; hard laws; activism; history of violence against women.

How to cite: Ticu, I. (2020). Short Incursion in the History of Domestic Violence. Logos Universality Mentality Education Novelty: Law, 8(1), 35-46. doi:10.18662/lumenlaw/8.1/34 


\section{Introduction}

The history of violence against women is not easily reconstituted starting from the scientific literature because more forms of violence - rape, sexual harassment, domestic violence - were all the while reported too rarely, precisely as an effect of the social norms, the stigma and because it is considered a taboo and sensible subject (Krug et al. 2002; Watts \& Zimmerman, 2002).

The article is realizing a summary description of the stages of the activism development aiming to stop the violence against women, starting from 1791, when the phenomenon begins to be recognized as being very dangerous because is breaking the fundamental human rights. The violence against women was a very hard to digest subject for the institutions of the states predominantly ruled by men; the rights of women were not a priority on their working agenda as the women were not able to defend their own status. As a reply to the Declaration of France concerning the human rights from 1791, Olympe de Gouges wrote „The Declaration of the Rights of Women and the Female Citizen". Article 1 of that declaration stipulated: "The woman is born and remains free and equal in rights with the men. Social distinctions may be based only on common utility" and article 2 is referring to the right of security and protection against any type of oppression: „The purpose of any political association is the preservation of the natural and imprescriptible rights of women and men; these rights are the property of liberty, security, and, particularly, the resistance to oppression” (Gay Levy et al., 1980, pp. 87-96).

\section{Definitions of the domestic violence}

Violence against women was quite an arduous legislative process until its international recognition. Only in December 1993, the Resolution of the General Assembly of the United Nations concerning the "Declaration on the Elimination of Violence against Women" becomes the first international instrument defining explicitly the phenomenon of violence against women, elaborating a series of discussions for its prevention (UN Women, n.d.). Previously to this period, the "Convention from 1979 concerning the elimination of all forms of discrimination against women" (CEDAW) is including VAW (Violence against Women) in its General Recommendations points 12 and 19 (United Nations, 2003), the Declaration and the Action Plan from Vienna, mentioning VAW at point 18 (UN General Assembly, 1993a). 
Article 2 of the Declaration of United Nations is defining and differentiating the violence against women in the following terms, not limited to: 1) Physical, sexual and psychological violence appeared within the family, including also mockery, sexual abuse of the feminine children from the household, violence connected to the dowry, marital rape, genital mutilation of the women and other traditional harmful practices, nonconjugal violence and violence connected to exploitation; 2) Physical, sexual and psychological violence appearing within the general community including rape, sexual abuse, sexual harassment and intimidation at the workplace, in education institutions and in other places, women trafficking and forced prostitution; 3) Physical, sexual and psychological violence committed by the state, stat, anywhere would happen (art.2, A/RES/48/104, 1993).

In a wider sense, domestic violence (Hanganu et. al., 2017, pp. 4658) can be defined as a threat or the execution of a bodily harm, in the past or present, within a couple living together. Violence in the family is at the origin of numerous physical and psychical diseases, can lead to frequent consultations, hospitalizations and temporary working incapacity, as well as incapacitate to a huge consume of medication and other health services. Other definitions of VAW are supplied by the Inter-American Convention from 1994 on the Prevention, Punishment, and Eradication of Violence against Women (Organization of American States/OAS, 1994).

Article 2 of the Inter-American Convention on the Prevention, Punishment and Eradication of Violence against Women, known as the Belém Do Pará Convention, is referring to the violence against women by differentiating the physical, sexual and psychological violence: violent act taking place in the family unit or within any other interpersonal relationship, no matter if the perpetrator is sharing or not the same household with the woman (Hunea, et al. 2017), including, among other things, rape, beating and sexual abuse; violence taking place in the community which is done by any person, including rape, sexual abuse, torture, trafficking, forced prostitution, kidnapping and sexual harassment at the workplace as well as in educational institutions, in health institutions or in any other place; which is committed or condemned by the state or its agents, regardless their whereabouts" (Organization of American States/OAS, 1994).

\section{The activism and violence against women}

Centre for Women, Peace and Security is developing a platform of support and information upon the violence against women - Tackling 
Violence against Women - which has the role to explain the legal role of the human rights globally and regionally and which is helping to stop the gender discrimination and violence against women and girls. This platform is offering clear information on the history of soft and hard legislation development against violence against women, but also on the globally campaign against this phenomenon, information especially destined to the organizations within the civil society and its supporters (Centre for Women, Peace and Security, 2016).

We would like to present the chronology of the fight for the freedom of women, as it was resumed by the Centre for Women, Peace and Security, an evolution of the international framework concerning the human rights. Due to article space reasons we shall present only some of the specific events of each period of development of the actions for the support and protection of the women rights and the cease of violence against them.

Period 1791 - 1945: During this period there were developed the first fighting actions against violence against women, we observe the first activists in many key development areas. Notable endeavors aligned with violence against women have started since the beginning of $19^{\text {th }}$ century. Internationally we can notice a series of declarations, manifests, publications sustaining the women rights and the cease of violence against them. Maybe the most important event in the history of the inception of the manifest for the women rights is the "International Congress of Women's Rights"; in 1878 it is organized in Paris, France, the first "International Congress of Women's Rights". Ten years later, in 1888, it was established the oldest International Organization of Women - the International Council of Women. At the second edition of the International Congress of Women's Rights, in 1902, a group is leaving the Council and so comes into being the International Alliance of Women.

The Congress is taking place also in 1915, and following an appeal addressed to all women, at the end of the Congress it is formed the Women's International League for Peace and Freedom.

Period 1945 - 1962: A transformation is taking place regarding the human rights legislation, marked by the beginning of the legal substantiation of the women rights; in 1946, "The Economic and Social Council of the United Nations" is instituting a "Commission on the Status of Women" (CSW) for the promotion of the "gender equality and the empowerment of women" (Resolution ECOSOC 11 (II).

Even if the women present at the Conference of the United Nations regarding the international organization were against, CSW was initially instituted as a sub-commission, which was placed under the general 
authority of the "Commission for Human Rights". Later, the position of independence as an organism by itself of CSW was obtained due to the "Resolution of the first president of the sub-commission for the Status of Women", Mrs. Bodil Begtrup from Denmark.

Period 1962 - 1975: It has as main manifesto the recognition of the women's role in the development; in 1967, the "Declaration on the Elimination of Discrimination against Women" has been issued by the General Assembly of the United Nations, asking the states to take appropriate measures to eliminate the harmful convictions about the women's inferiority. The General Assembly of the United Nations has a specific role in sustaining the actions of elimination of violence against women, through the adoption of those soft laws which put pressure on the gradual and continuous development of a system favorable to the development of women in the society.

Period 1975 - 1985 is called "United Nations Decade for Women" and has as goal the focus upon the politics and problems that are affecting women, such as wage equity, violence based on sex, the right of property upon the lands and other human rights; it was adopted on December 15, 1975 by the General Assembly of the United Nations through the Resolution 31/136.

In 1979 it is created an international project for the women's rights: the "Convention on the Elimination of All Forms of Discrimination against Women”. „Violence against women” is not a subject expressly mentioned in this convention, but article 6 foresees that „the state parties will take all adequate measures, including the legislation, to suppress all forms of women trafficking and the exploitation of women prostitution" (Centre for Women, Peace and Security, n.d.). In 1985 the General Assembly of the United Nations is adopting the Resolution 40/36, the first resolution on domestic violence. The adoption of this resolution was influenced by the sixths "Congress of the United Nations on the Prevention of Crime and the Treatment of Offenders", as well as by the recommendations issued by the Commission regarding the status of women.

Period 1986-1995: Development stage of the women's rights and of the fight against gender-based violence concentrated on obtaining equality, development and peace. In 1991 it takes place the fist manifesto of 16 days to stop violence against women, in all its forms. The manifesto took place starting from November 25, the "International Day for the Elimination of Violence against Women" and ended on December 10, on Human Rights Day. After this manifesto, more than 1,000,000.00 signatures were gathered from 124 countries, asking to the "World Conference of Human Rights" 
held by United Nations to officially recognize gender-based violence as an issue of human rights.

In 1993 it is adopted the "Declaration on the Elimination of Violence against Women", by the General Assembly of the United Nations, through the Resolution 48/104. According to this resolution, United Nations are making known their position towards the forms of violence they fight against. According to UN (1993b), violence against women is ,any act of gender-based violence that results in, or is likely to result in, physical, sexual or psychological harm or suffering to women, including threats of such acts, coercion or arbitrary deprivation of liberty, whether occurring in public or in private life" (United Nations General Assembly, A/RES/48/104).

Period 1995-2016: From 1995 up till now, globally, it is sustained the empowerment of women, the justice and the sustainable development.

1995: At the end of the fourth "World Conference on Women" from Beijing, China, the "Beijing Declaration" and the "Platform for Action" are adopted and become the most vast and complete agreement in the world regarding the empowerment of women and gender equality.

1996: Reference cases on VAW: Aydin v. Turkey.

1997: Bringing men in action for women: a set of four high level conferences are organized in order to examine the problem of violence with women victims as a "male issue", "male culture" and the impact of this violence against men and the whole society.

1997: The General Assembly of the United Nations is adopting a „Model of Strategies and Practical Measures on the Elimination of Violence against Women in the Field of Crime Prevention and Criminal Justice" (Resolution 52/86).

1998: "Rome Statute of the International Criminal Court" is recognizing in its jurisdiction, numerous gender-based offenses as "war crimes, crimes against the humanity and genocide, including rape, sexual slavery, forced prostitution, forced pregnancy, forced sterilizations, genderbased persecutions, on the person, especially of women and children, and sexual violence" (Rome Statute of the International Criminal Court, 1998).

1999: It comes into force the optional protocol at the "Convention on the Elimination of all Forms of Discrimination against Women".

2000: Beijing +5: „Women 2000: Gender Equality, Development and Peace for the Twenty-first Century".

2000: "Plan on Women, Peace, and Security": it is adopted the Resolution S/RES/1325 of the United Nations Security Council. It is acknowledged the fact that the "armed conflict has a differential and unique 
impact upon women, and their participation is essential in conflict resolution and in sustainable peace building" (United Nations Security Council, 2000).

2003: Approaching VAW in Africa: it is adopted the "Protocol to the African Charter on Human and Peoples' Rights on the Rights of Women in Africa", known as the Maputo Protocol.

2004: Approaching VAW in South Asia: the "Declaration on the Elimination of Violence against Women in the ASEAN region" is adopted.

2004: Reference cases on VAW: "Meija v. Peru".

2005: Beijing +10: On the $49^{\text {th }}$ session of the "Commission on the Status of Women" it was underlined that with no exception, the states must efficiently enforce the "Beijing Platform for Action", including the elimination of violence against women, in order to fulfill the development commitments.

2006: It is launched the in-depth study of the Secretary-General of the United Nations Organization on all forms of violence against women. This is the first comprehensive report of the Secretary-General of the United Nations on this matter.

2007: The "Special Court for Sierra Leone" had offered a decision acknowledging that "the forced marriage acts were as severe as many other crimes against humanity, including enslavement, imprisonment, torture, rape, sexual slavery and sexual violence".

2008: The United Nations Secretary-General is launching the campaign „UNiTE to end Violence against Women”.

2010: It is created the "United Nations entity for gender equality and the empowerment of women" named United Nations Women. This entity is combining four parts of the United Nations system dedicated to gender equality and the empowerment of women: the "Division for the Advancement of Women (DAW)"; the "International Research and Training Institute for the Advancement of Women (INSTRAW)"; the "Office of the Special Adviser on Gender Issues and Advancement of Women (OSAGI)"; the "United Nations Development Fund for Women (UNIFEM)".

2011: Reference cases on VAW: "EIPR and Interights v. Egypt".

2011: Approaching VAW in Europe: adopting the "Council of Europe Convention on preventing and combating violence against women and domestic violence", known as the Istanbul Convention.

2011: Combating VAW in the Middle East and North Africa: the Arab Strategy for Combating 2011-2020.

2012: Combating VAW in the Pacific Islands: the "Pacific Leaders Gender Equality Declaration" is adopted. 
2013: It is adopted the "Declaration on the Elimination of Violence against Women and Children" in ASEAN region.

2014: The "Office of the Prosecutor for the International Criminal Tribunal for Rwanda": it is launched the "Manual for the best practices in the research and prosecution of the crimes of sexual violence in the postconflict regions".

2014: 1,000.00 delegates and 123 county delegates, including 79 ministers are participating to the first "Global Summit to end Sexual Violence in Conflict".

2014: The "United Nations High Commissioner for the Human Right"s is publishing „The Latin-American Protocol for the investigation of gender-related killings of women" in order to fight the impunity for femicide in Latin America.

2015: Beijing +20: On the $59^{\text {th }}$ session of the "Commission on the Status of Women", it was underlined the actual challenges which have impacted the implementation of the "Beijing Platform for Action" and have hindered women empowerment.

2015: The transformation of our world: the General Assembly of United Nations is adopting the Sustainable Development Goals - one of the goals is aiming specifically the elimination of all forms of violence against women and girls, while other goals are relevant for this effort (Resolution $70 / 1)$.

2015: The Revision after 15 years since the implementation of Security Council Resolution 1325: United Nations Women is launching the global study „Preventing Conflict, Transforming Justice, Securing the Peace".

2016: The case Jean-Pierre Bemba Gombo: the First International Criminal Court case concentrated upon the sexual crimes had adopted a decision acknowledging the use of sexual violence as weapon of war (https://blogs.lse.ac.uk/vaw/).

\section{Conclusions:}

This short incursion in the history of violence against women is showing that this phenomenon has been always manifested, and over time was tolerated, and in some cultures even imposed by the predominantly religious and ossified political system which pretended to be defending the family morality. Studying the man as a social human being, Aristotle considered „violence as being the lack of education and knowledge" (Rațiu \& Hizo-Miloş, 2016), while another great thinker, Thomas Hobbes (as cited 
by Helmisaari, 2011) considered violence as being the result of the man's own fears of uncertainty. In the current context, most of the civilized states are working real hard to prevent and combat the phenomenon of violence against women.

The development of the socio-human sciences and of the egalitarian currents has led to addressing this field of interest. The costs of the medical condition treatments generated by violence have determined the deciders to implement a series of public policies and laws to prevent and diminish this phenomenon.

If until 50 years ago violence against women was considered to be an issue of the personal life, starting with 1970, the feminist movement led gradually to the transfer of this subject from the private area to the public one, belonging to the civilized states. Later on, the interest manifested for the study of violence against women manifested within marital relations is relatively recent. This course from the private into the public sphere had succeeded to attract a greater involvement of the responsible authorities for insuring the health, protecting the human rights and social justice (Dima \& Beldianu, 2015). Moreover, the pathfinder states have ensured the legal framework for the authorities involved in the prevention and decrease of the violence against women to be able to intervene in the sphere considered no long ago „private” in order to take all appropriate measures.

\section{References}

African Commission on Human and Peoples' Rights. (2011). EIPR and Interights v. Egypt. https://africanlii.org/afu/judgment/african-commission-humanand-peoples-rights/2011/85

African Union. (2003). Protocol to the African Charter on Human and Peoples' Rights on the Rights of Women in Africa. https://au.int/en/treaties/ protocol-african-charter-human-and-peoples-rights-rights-women-africa

Arab Women Organization. (2011). The Arab Strategy for Combating Violence against Women 2011-2020. http://www.arabwomenorg.org/content/ publications/vaweng.pdf

ASEAN Commission on the Rights of Women and Children (ACWC). (2013). Declaration on the Elimination of Violence against Women and Children in ASEAN. https://www.asean.org/storage/images/archive/23rd ASEANSummit $/ 6 . \% 20$ declaration $\% 20$ on $\% 20$ evawc $\% 20$ in $\% 20$ asean $\% 20$ \%20final.pdf

Centre for Women, Peace and Security. (2016). Tackling violence against women. https://lsedesignunit.com/VAW timeline/index.html 
Commission on the Status of Women. (1946). Resolution ECOSOC 11 (II) adopted 21 June 1946 (document E/90 and document E/84, paragraph 6). https://undocs.org/en/E/RES/11(II)

Council of Europe. (2011). Convention on preventing and combating violence against women and domestic violence. https://www.coe.int/en/web/ gender-matters/council-of-europe-convention-on-preventing-andcombating-violence-against-women-and-domestic-violence

De Gouges, O. (1791). The Declaration of the Rights of Women and the Female Citizen. https://revolution.chnm.org/d/293

Declaration on the Elimination of Violence against Women in the ASEAN region. (2012). https://asean.org/?static post=declaration-on-the-elimination-ofviolence-against-women-in-the-asean-region-4

Dima, G., \& Beldianu, I. F. (Coords.). (2015). Violenţa domestică: Intervenţia coordonată a echipei multidisciplinare. Manual pentru specialisti [Domestic violence: Coordinated intervention of the multidisciplinary team. Manual for specialists]. Editura de Vest.

European Court of Human Rights. (1997). Aydin v. Turkey. https://hudoc.echr. coe.int/fre\# $\{\% 22$ itemid $\% 22:[\% 22001-58371 \% 22]\}$

Gay Levy, D., Branson Applewhite, H., \& Durham Johnson, M. (Eds.). (1980). Women in revolutionary Paris, 1789-1795. University of Illinois Press.

Hanganu, B., Crauciuc, D., Petre-Ciudin, V., Velnic, A. A., Manoilescu, I., \& Ioan, B. G. (2017). Domestic violence in the postmodern society: Ethical and forensic aspects. Postmodern Openings, 8(3), 46-58. https://doi.org/10.18662 $\angle \mathrm{po} / 2017.0803 .05$

Helmisaari, V. (2011). Theoretical approaches to violence: René Girard and Thomas Hobbes. https://ecpr.eu/Events/Event/PaperDetails/8764

Hunea, I., Damian, S. I., Knieling, A., David, S., Diac, M., \& Bulgaru Iliescu, D. (2017). The victim of violence - Between the law and the aggressor. Logos Universality Mentality Education Novelty: Law, 5(2), 17-25. https://doi.org/ 10.18662/lumenlaw.2

Inter-American Commission on Human Rights (IACHR). (1996). Meija v. Peru. https://www.refworld.org/cases,IACHR,3ae6b71c6.html

Krug, E. G., Dahlberg, L. L., Mercy, J. A., Zwi, A. B., \& Lozano, R. (2002). The world report on violence and health. The Lancet, 360(9339), 1083-1088. https://doi.org/10.1016/S0140-6736(02)11133-0

Office of the Prosecutor for the International Criminal Tribunal for Rwanda. (2014). Best practices manual in the investigation and prosecution of sexual violence crimes in post-conflict regions. https://unictr.irmct.org/sites/ unictr.org/files/legal-library/140130 prosecution of sexual violence.pdf 
Organization of American States (OAS). (1994). Inter-American Convention on the Prevention, Punishment and Eradication of Violence against Women. Belém Do Pará Convention. https://www.refworld.org/docid/3ae6b38b $\underline{\text { 1c.html }}$

Pacific Islands Forum. (2012). Pacific Leaders Gender Equality Declaration. https://www.forumsec.org/2012/08/30/pacific-leaders-gender-equalitydeclaration/

Rațiu A. M., \& Hizo-Miloş, L. S. (2016). Violenţa domestică [Domestic violence] (1st vol.) Aspecte generale [General considerations]. Napoca Star.

Rome Statute of the International Criminal Court. (1998). https://www.un.org/law $\angle$ icc/index.html

The Declaration of the Rights of Man and of the Citizen (1791). https://courses.lumenlearning.com/suny-hccc-worldhistory2/chapter/thedeclaration-of-the-rights-of-man/\#: :text=Intellectual $\% 20$ Context,The $\% 20$ Declaration $\% 20$ of $\% 20$ the $\% 20$ Rights $\% 20$ of $\% 20$ Man $\% 20$ and $\% 20$ of $\% 20$ the, of $\% 20$ human $\% 20$ and $\% 20$ civil $\% 20$ rights.\&text=The $\% 20$ docum ent $\% 20$ defines $\% 20 \mathrm{a} \% 20$ single,collective $\% 20$ rights $\% 20$ for $\% 20$ all $\% 20$ men.

UN Women. (n.d.). Global norms and standards: Ending violence against women. https://www.unwomen.org/en/what-we-do/ending-violence-againstwomen/global-norms-and-standards

United Nations General Assembly. (1976). Resolution 31/136 adopting the period from 1976 to 1985 as the United Nations Decade for Women: Equality, Development and Peace. https://digitallibrary.un.org/record/199700? $\ln =\mathrm{en}$

United Nations General Assembly. (1979). Convention on the Elimination of all Forms of Discrimination Against Women (CEDAW). https://www.ohchr. org/en/professionalinterest/pages/cedaw.aspx

United Nations General Assembly. (1985). Resolution 40/36 on domestic violence. https://www.unodc.org/documents/commissions/CCPCJ/Crime_Resolu tions/1980-1989/1985/A-RES-40-36.pdf

United Nations General Assembly. (1993a). Vienna Declaration and Programme of Action. https://www.refworld.org/cgi-bin/texis/vtx/rwmain?page=topic \&tocid $=459 \mathrm{~d} 17822 \&$ toid $=459 \mathrm{~b} 17 \mathrm{a} 82 \& \mathrm{docid}=3 \mathrm{ae} 6 \mathrm{~b} 39 \mathrm{ec} \&$ skip $=\mathrm{O}$

United Nations General Assembly. (1993b). A/RES/48/104 - Declaration on the Elimination of Violence against Women. http://www.un-documents.net/ a48r104.htm

United Nations General Assembly. (1999). The Optional Protocol to the Convention on the Elimination of All Forms of Discrimination against Women (OP-CEDAW). https://treaties.un.org/Pages/ViewDetails.aspx? $\underline{\text { src }=\text { TREATY\&mtdsg no }=I V-8-b \& \text { chapter }=4 \& c l a n g=\text { en }}$ 
United Nations General Assembly. (2000). Women 2000: Gender Equality, Development and Peace for the Twenty-first Century. https://www.un. org/womenwatch/daw/followup/session/presskit/gasp.htm

United Nations General Assembly. (2011).Resolution 52/86 - Model of Strategies and Practical Measures on the Elimination of Violence against Women in the Field of Crime Prevention and Criminal Justice. https://www.unodc. $\mathrm{org} /$ documents/justice-and-prison-reform/crimeprevention/Model

$\underline{\text { Strategies and Practical Measures on the Elimination of Violence agai }}$ nst Women in the Field of Crime Prevention and Criminal Justice.pdf

United Nations General Assembly. (2015). A/RES/70/1 - Transforming our world: the 2030 Agenda for Sustainable Development. https://sustainable development.un.org $/$ index.php?page $=$ view\&type $=111 \& n r=8496 \&$ menu $=35$

United Nations High Commissioner for the Human Rights. (2014). The LatinAmerican Protocol for the investigation of gender-related killings of women. https://eurogender.eige.europa.eu/system/files/events-files/latin american protocol for investigation of femicide.pdf

United Nations Security Council. (2000). Resolution S/RES/1325 on women, peace, and security. https://undocs.org/S/RES/1325(2000)

United Nations Women. (2015). Preventing Conflict, Transforming Justice, Securing the Peace. https://www.peacewomen.org/sites/default/files/ UNW-GLOBAL-STUDY-1325-2015\%20(1).pdf

United Nations. (1995). Beijing Declaration and the Platform for Action. https://www.un.org/en/events/pastevents/pdfs/Beijing_Declaration_and Platform for Action.pdf

United Nations. (2003). General Recommendations adopted by the Committee on the Elimination of Discrimination against Women. https://www.un.org/ womenwatch/daw/cedaw/recommendations/

Watts, C., \& Zimmerman, C. (2002). Violence against women: global scope and magnitude. The Lancet, 359(9313), 1232-1237. https://doi.org/10.1016/ $\underline{\text { S0140-6736(02)08221-1 }}$ 